\title{
INTRODUKSI TTG PASCA PANEN DAN PENGOLAHAN KOPI PADA INDUSTRI RUMAH TANGGA GUNA MENINGKATKAN NILAI TAMBAH DI KECAMATAN TANJUNG KABUPATEN LOMBOK UTARA
}

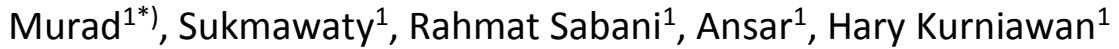 \\ ${ }^{1}$ Program Studi Teknik Pertanian, Fakultas Teknologi Pangan dan Agroindustri \\ Universitas Mataram \\ ${ }^{*}$ Korespondensi: muradfatepa@unram.ac.id
}

Diterima 4 November 2019 / Disetujui 5 Januari 2020

\begin{abstract}
ABSTRAK
Kopi merupakan salah satu komoditas unggulan di Pulau Lombok khususnya di Lombok Utara. Jenis kopi yang ditanam adalah robusta (Robusta canephorapierre) dan kopi sambung (robusta arabika). Kopi jenis ini yang memiliki karakter organoleptik tersendiri yang potensial untuk dikelola guna meningkatkan kesejahteraan para petaninya dan masyarakat pada umumnya. Proses pengolahannya masih dilakukan secara tradisional. Meskipun prospek pengembangannya menjanjikan, akan tetapi muatan teknologi pada komoditas ini sangat masih minimal sehingga nilai tambah yang diperoleh petani relatif terbatas. Tujuan dari kegiatan ini adalah untuk menemukan strategi alih dan penerapan teknologi tepat guna (TTG) pasca panen dan pengolahan kopi pada industri rumah tangga guna meningkatkan nilai tambah di Kecamatan Tanjung Kabupaten Lombok Utara. Kegiatan ini dilakukan melalui pelatihan serta demonstrasi menggunakan metode Pendidikan Orang Dewasa (POD) dengan menekankan partisipasi aktif peserta, kerja kelompok, dan demonstrasi penerapan teknologi tepat guna pasca panen dan pengolahan kopi pada industri rumah tangga di Kecamatan Tanjung Kabupaten Lombok Utara. Hasil kegiatan ini diharapkan dapat menjadi acuan bagi masyarakat petani kopi dan pemerintah daerah dalam mewujudkan strategi pengembangan komoditas kopi melalui introduksi teknologi tepat guna pasca panen dan pngolahan kopi. Hasil pelaksanaan kegiatan pengabdian yang telah dilakukan bahwa mulai dari pasca panen biji kopi telah dilakukan kegiatan sortasi dan grading dengan menggunakan alat grading screen ukuran lubang no 10 diameter $6 \mathrm{~mm}$, no 15 diameter $7 \mathrm{~mm}$ dan no 20 diameter $8 \mathrm{~mm}$. Hasil grading biji kopi diperoleh ukuran kelas mutu/grade I ukuran biji kopi di atas $8 \mathrm{~mm}$, mutu/grade II ukuran $8 \mathrm{~mm}$ dan mutu/grade III ukuran $7 \mathrm{~mm}$ sedangkan biji yang lolos dengan ukuran $\leq 6 \mathrm{~mm}$ termasuk biji rusak. Grading biji kopi yang telah dilakukan dapat meningkatkan nilai jual secara nyata dengan perolehan $\mathrm{Gl} \pm 60 \%$ (Rp. 50.000 per kg), GII $\pm 20 \%$ (Rp. 35.000 per $\mathrm{kg}$ ) dan GIII $\pm 20 \%$ (Rp. 15.000 per kg). Jadi total nilai tambah diperleh rata-rata sebesar 15-20\%. Proses pengolahan biji kopi dilakukan dengan menggunakan alat Roaster tipe silinder dengan kapasitas 5-10 kg untuk penyangraian (roasting) biji kopi yang dilakukan dengan system pengendalian proses, sehingga biji kopi sangrai yang diperoleh sesuai target tingkat pemasakan dengan suhu rata-rata $200^{\circ} \mathrm{C}$ selama $1-1,5$ jam. Penanganan selanjutnya adalah pengemasan produk olahan biji kopi yang meliputi biji kopi mentah (greenbean), biji kopi sangrai dan kopi bubuk dengan berbagai jenis dan tingkat mutu (original, fermium, dan clasik). Produk kopi hasil olahan dalam bentuk kemasan dipasarkan melalui kegiatan penitipan di
\end{abstract}


berbagai supermarket, kegiatan pameran dan bahkan ada yang langsung datang membeli maupun pemesanan secara online.

Kata kunci: introduksi, TTG, pasca panen, pengolahan, kopi

\section{PENDAHULUAN}

Salah satu produk unggulan di Kabupaten Lombok Utara adalah Kopi. Produk ini memiliki potensi yang besar dan sangat potensial untuk dikembangkan sebagai salah satu produk andalan untuk menopang perekonomian masyarakat dan mendukung destinasi wisata. Produk ini masih dikelola secara konvensional dan diperlukan upaya untuk pengembangnnya agar memiliki nilai ekonomi tinggi. Salah satu aspek yang penting untuk dilakukan adalah pengembangan produk dan pengemasannya, sehingga dapat diterima oleh pasar yang lebih luas bersaing dengan produk sejenis di pasar kopi.

Tantangan yang dihadapi oleh masyarakat dan pemerintah kabupaten Lombok Utara adalah bahwa komoditas ini masih diusahakan secara konvensional sehingga belum dapat memberikan nilai dan manfaat yang significant dalam perkembangan ekonomi masyarakat dan perekonomian daerah. Sesungguhnya produk ini memiliki potensi yang cukup besar, karena memiliki lahan budidaya yang luas dan masyarakat telah memiliki pengalaman dan keterampilan yang cukup baik dalam aspek budidaya tanaman kopi, sehingga kabupaten Lombok Utara merupakan salah satu daerah pemghasil komoditas kopi yang sangat potensial. Untuk itulah Pemerintah Kabupaten Lombok Utara telah menetapkan komoditas kopi sebagai salah satu komoditas unggulan daerah selain kelapa dan kakao.

Permasalahannya adalah bahwa kopi yang dihasilkan masyarakat yang demikian besar jumlahnya, masih terbatas pada aspek pasca panen nya. Produk ini umumnya dijual dalam bentuk bijian kering panen (gelondongan) kepada pedagang lokal maupun kepadsa pedagang besar dari luar daerah. Sebagian kecil diolah menjadi produk kopi yang dilakukan secara konvensional dan belum dilakukan secara baik menggunakan teknologi dan manajemen usaha yang baik, sehingga produk kopi yang ada belum memiliki nilai ekonomi yang tinggi dan pemasarannya masih terbatas.

Untuk itu, sejalan kebijakan dan arah pengembangan pembangunan daerah yang telah dicanangkan oleh pemerintah daerah untuk menjadikan kopi sebagai produk andalan yang memiliki daya saing dan diharapkan dapat menjadi penggerak perekonomian masyarakat dan daerah, diusulkan untuk dilakukan pelatihan teknis dan manajemen usaha pengolahan kopi di Kabupaten Lombok Utara.

Kemudian saat penanganan pasca panen, penjemuran kopi umumnya dilakukan ditepi jalan atau tempat-tempat yang sanitasinya tidak memadai, sehingga terkontaminasi berbagai kotoran. Disamping itu, penjemuran yang dilakukan tidak dapat mencapai kadar air maksimum yang diizinkan yaitu $12,5 \%$, sehingga biji kopi sering berjamur. Lebih lanjut, alat pengupas kopi yang digunakan umumnya tidak memenuhi standar, sehingga biji kopi yang dihasilkan banyak yang pecah.

Disamping itu, cara dan tempat untuk menyimpan hasil yang tidak memadai menyebabkan meningkatnya kadar kotoran dan kadar air. Akibatnya mutu biji kopi yang dihasilkan petani paling banter grade IV. Penanganan pasca panen tersebut sulit diperbaiki karena tidak ada insentif harga, kopi bermutu baik dihargai hampir sama dengan kopi bermutu rendah. 
Petani merasa lebih untung menghasilkan kopi dengan mutu seadanya tanpa harus mengorbankan waktu dan biaya untuk memperbaiki mutu kopi yang mereka hasilkan. Jadi selama ada pasar yang dapat menyerap produksi mutu rendah, maka sulit diharapkan petani memperbaiki mutu kopinya.

Kondisi tersebut menunjukkan bahwa perbaikan mutu kopi membutuhkan kerja keras terutama untuk mensosialisasikannya kepada jutaan petani kopi Indonesia dan tugas ini merupakan taruhan masa depan perkopian Indonesia. Apabila hal ini tidak ditangan secara tepat maka ekspor kopi Indonesia akan turun dan pasar kopi domestik akan kelebihan penawaran yang pada gilirannya akan menurunkan harga kopi.

\section{METODE KEGIATAN}

Adapun permasalahan sangat
penting yang harus dicari jalan pemecahannnya pada masyarakat industri kecil atau industri rumah tangga (home industries) pasca panen dan pengolahan kopi adalah pada teknik proses fermentasi yang masih sederhana (tradisional), system pengeringan dan pengolahan kopi masih sederhana sehingga produk kopi yang dihasilkan tidak seragam mutu dan kualitasnya. Jika tidak memperhatikan proses yang terstandarisasi, maka akibatnya produk tersebut menjadi kurang diminati dan kalah bersaing di pasaran dengan produk sejenis lainnya.

Sebagai alternative untuk memecahkan permasalahan tersebut adalah dengan dilakukannya introduksi TTG pasca panen dan pengolahan kopi pada industri rumah tangga di Kecamatan Tanjung Kabupaten Lombok Utara. Dengan diaplikasikannya TTG metode ini, akan mampu meningkatkan daya saingap rodukdi pasaran sebagai produk yang dapat ijadikan sebagai produk unggulan yang bernilai ekonomi tinggi.

Kegiatan ini dilakukan melalui Pelatihan serta demonstrasi dengan menggunakan metode Pendidikan Orang Dewasa (POD) atau Androgogi dengan menekankan partisipasi aktif dari peserta (kelompok sasaran), kerja kelompok dan demonstrasi penerapan teknologi tepat guna teknik penanganan pasca panen dan pengolahan kopi serta pengemasannya pada skala home idustries.

\section{HASIL DAN PEMBAHASAN}

Kopi merupakan produk hasil perkebunan sebagai salah satu produk unggulan di Nusa Tenggara Barat, khususnya di Kabupaten Lombok Utara. Produksi kopi di Kabupaten Lombok Utara cukup melimpah, fluktuasi harga kopi relatife tinggi yang cukup berdapak pada upaya peningkatan kesejahteraan masyarakat.

Mengenai penanganan pasca panen kopi masih minim dilakukan, hal ini disebabkan karena masih kurangnya pengetahuan masyarakat dalam penanganan pasca panen dan atau pengolahan kopi. Sebagian besar produk kopi dipasarkan dalam bentuk gelondong atau biji kopi mentah (green bean), ada sebagian dari masyarakat yang melakukan pengolahan kopi menjadi bubuk kopi tetapi masih dilakukan secara tradisional. Dengan demikian produk olahan kopi yang dihasilkan memiliki mutu dan kualitas yang masih rendah.

Aplikasi ipteks berupa penerapan teknologi tepat guna pasca panen dan pengolahan kopi pada industri rumah tangga dilakukan untuk meningkatkan nilai tambah dan harapannya dapat meningkatkan kesejahteraan masyarakat. Kegiatan yang selama ini dilakukan oleh Perguruan Tinggi terhadap kelompok industri rumah tangga (home industries) 
lebih banyak dititik beratkan pada proses pembuatan baik dari awal proses sampai akhir proses menjadi produk jadi yang meliputi ; proses pemanenan, penanganan pasca panen (pengeringan, pengupasan kulit, sortasi dan grading), pengolahan (penyangraian / roasting, pembubukan / penggilingan), dan pengemasan.

$$
\text { Beberapa permasalahan sangat }
$$

penting yang harus dicari jalan pemecahannnya pada kelompok industri kecil atau industri rumah tangga (home industries) pasca panen dan pengolahan kopi adalah masih rendahnya mutu dan kualitas produk yang dihasilkan dikarenakan cara penanganan dan pengolahan yang dilakukan masih kurang optimal bahkan sebagian besar dengan cara tradisional, sehingga nilai jual produk yang dihasilkan masih rendah. Jika tidak memperhatikan proses yang terstandarisasi, maka akibatnya produk tersebut menjadi kurang diminati dan kalah bersaing di pasaran dengan produk sejenis lainnya.

$$
\text { Sebagai alternatif untuk }
$$
memecahkan beberapa permasalahan tersebut adalah dengan dilakukannya introduksi teknologi tepat guna pada proses penanganan pasca panen dan pengolahan kopi serta penggunaan teknologi kemasan untuk dapat meningkatkan daya simpan produk serta meningkatkan nilai jual. Dengan diaplikasikannya metode ini, diharapkan mampu meningkatkan daya saing di pasaran sebagai produk yang dapat dijadikan sebagai produk unggulan yang bernilai ekonomi tinggi, sehingga dapat memberikan konstribusi bagi peningkatan kesejahteraan masyarakat serta peningkatan pendapatan asli daerah. Dengan demikian melalui kegiatan semacam ini diharapkan dapat meningkatkan pembangunan ekonomi daerah serta dapat menurunkan angka kemiskinan.

\section{Kegiatan Survey}

Sebelum pelaksanaan pelatihan dilakukan, terlebih dahulu telah dilakukan survey untuk mengidentifikasi kelompok masyarakat usaha rumah tangga yang beraktifitas dalam penanganan pasca panen dan pengolahan kopi. Dari hasil identifikasi diperoleh kelompok industri rumah tangga bergerak dalam bidang penanganan pasca panen dan pengolahan kopi dengan nama kelompok "NINA PACU" yang beranggotakan 15 (lima belas) orang dengan alamat Kecamatan Tanjung Kabupaten Lombok Utara.

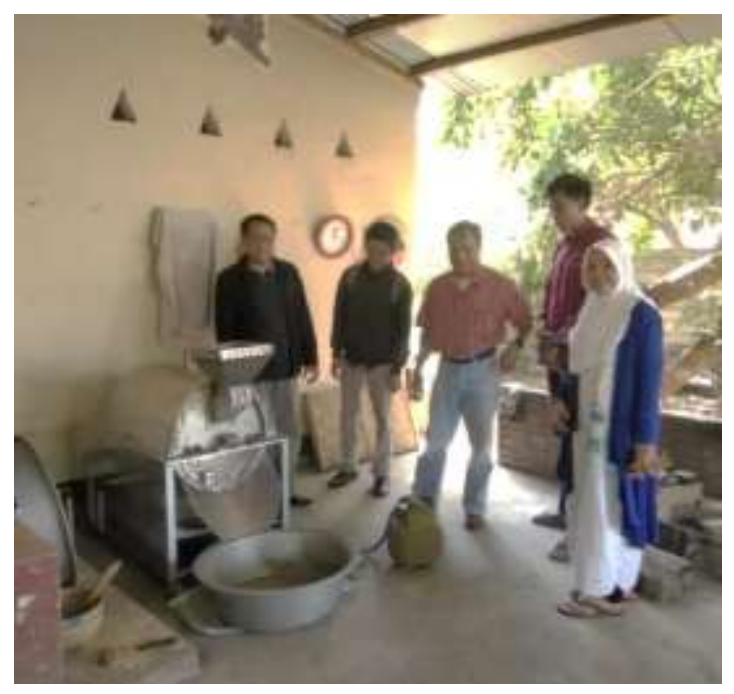

Gambar 1. Foto Kegiatan Survey

\section{Kegiatan Pelatihan di Tingkat Kelompok}

Pelaksanaan Pelatihan Introduksi TTG penanganan pasca panen dan pengolahan kopi di Kecamatan Tanjung Kabupaten Lombok Utara, terlebih dahulu masing-masing anggota kelompok menyiapkan bahn-bahan dan peralatan yang diperlukan serta beberapa kebutuhan penunjang lainnya.

Mekanisme pelaksanaan pelatihan meliputi ; acara pembukaan atau pengantar, penyampaian materi gambaran umum tentang tanaman kopi dan teknologi pasca panen kopi serta pengolahan kopi, materi gambaran umum tentang mesin peralatan yang digunakan dalam 
penanganan pasca panen dan pengolahan kopi, demonstrasi atau praktek penanganan pasca panen kopi seperti sortasi dan grading biji kopi, praktek pengolahan biji kopi yang meliputi penyangraian, penepungan dan pengemasan.

\section{Pembukaan dan Penyampaian Materi Pelatihan}

Rangkaian dari kegiatan pelatihan bagi peserta kelompok penanganan pasca panen dan pengolahan kopi diawali dengan penyampaian beberapa materi sebelum dipraktekkan atau didemonstrasikan. Materi yang disampaikan adalah : Gambaran umum tentang tanaman kopi, pasca panen dan pengolahan kopi yang disampaikan oleh Rahmat Sabani, STP.,MP., Gambaran umum tentang teknik penanganan pasca panen dan pengolahan kopi serta pengemasan dan penyimpanan disampaikan oleh Murad, SP.,MP., Gambaran umum tentang penggunaan mesin peralatan yang digunakan dalam penanganan pasca panen dan pengolahan kopi disampaikan oleh Dr. Ansar, S.Pd.,MP.,M.Pd, Gambaran umum tentang pengoperasian dan pemeliharaan alat disampaikan oleh Ammudin, STP.M.Si. Materi yang disampaikan disesuaikan dengan kondisi SDM peserta dan tujuannya untuk mempermudah dalam pelaksanaan praktek. Hal ini lebih ditekankan pada pembekalan petunjuk pelaksanaan proses dan penggunaan alat.

Kegiatan Pelatihan Introduksi TTG pasca panen dan pengolahan kopi di Kecamatan Tanjung Kabupaten Lombok Utara seperti ditunjukkan pada Gambar 2.

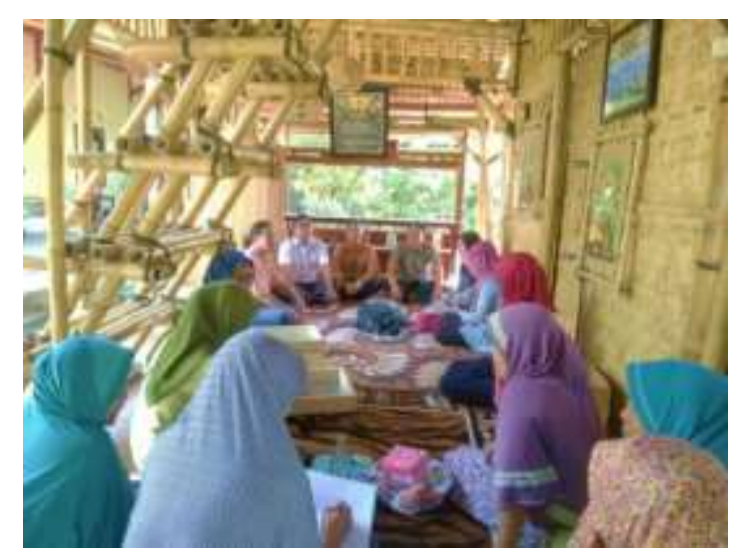

Gambar 2. Foto acara pembukaan dan penyampaian materi pelatihan

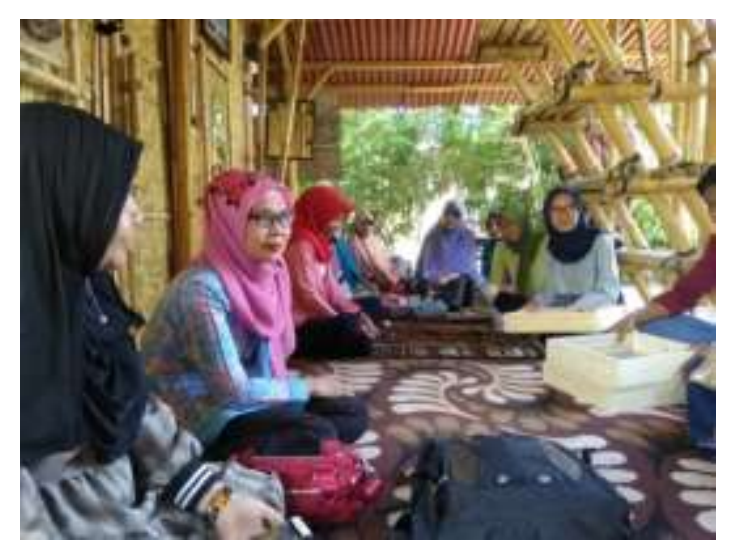

Gambar 3. Foto peserta pelatihan

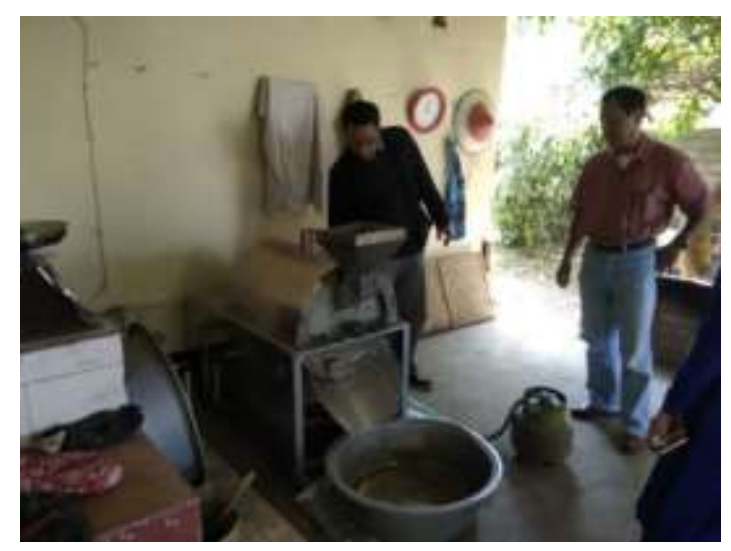

Gambar 4. Foto penjelasan penggunaan peralatan

\section{Kegiatan Praktek Penerapan TTG}

Pelaksanaan praktek atau demonstrasi penerapan TTG dimulai dari tahap awal sampai dengan tahap akhir oleh masing-masing anggota kelompok pada 
setiap tahapan proses. Pelaksanaan praktek dilakukan dengan didampingi oleh 3 orang mahasiswa yang dilibatkan sebagai tim dalam pelaksanaan kegiatan ini dan merupakan mahasiswa yang fokus penelitiannya tentang kopi. Dengan demikian pelaksanaan praktek lebih dititik beratkan pada penggunaan dan pengoperasian alat dan mesin yang lebih detail dan terarah, disamping itu juga mahasiswa dapat menerapkan dan menguji langsung di lapangan hasil penelitian yang telah dilakukan.

Kegiatan praktek ini meliputi ; persiapan bahan (biji kopi sambung) yang diperoleh dari petani seputaran Tanjung dan Gangga serta mesin peralatan yang diperlukan (alat sortasi dan grading berupa screen ayakan dengan ukuran diameter lubang $6 \mathrm{~mm}$ no 10, no 15 diameter $7 \mathrm{~mm}$ dan no 20 diameter $8 \mathrm{~mm}$ ), alat dan mesing penyangrai (roaster) semi otomatis tipe silinder berputar dengan kapasitas tabung 5-10 kg, alat dan bahan kemasan dengan berbagai jenis bahan dan ukuran.

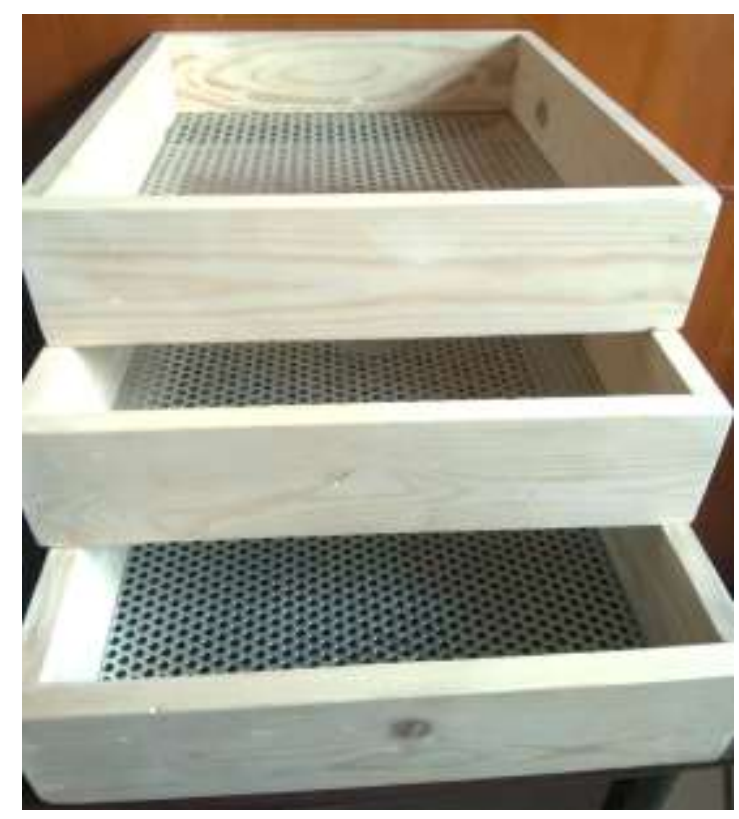

A

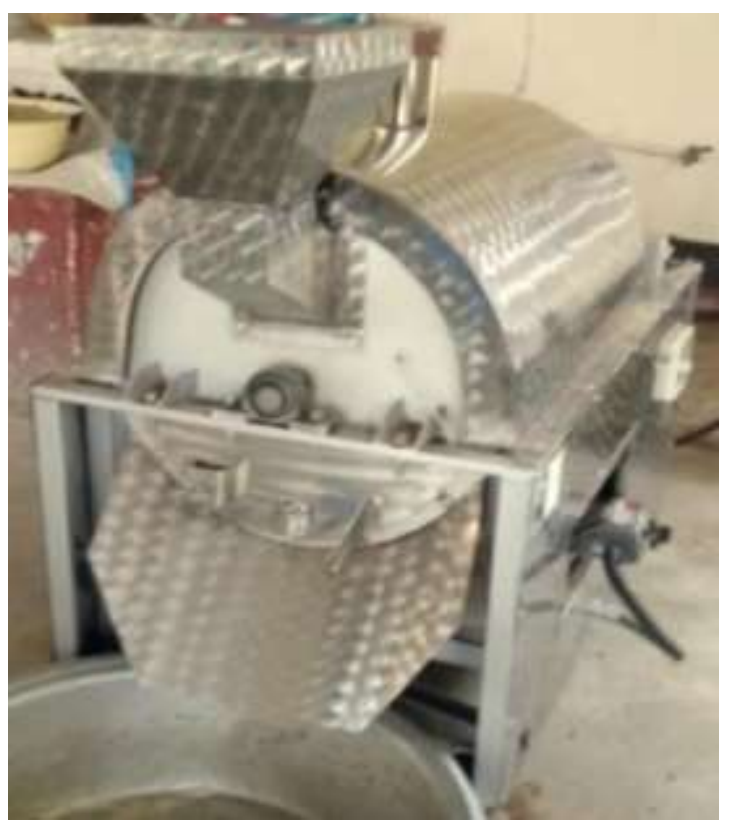

B

Gambar 5. Foto alat grading biji kopi model scren dan mesin roasting biji kopi

Kegiatan penerapan TTG penanganan pasca panen kopi, salah satunya adalah menentukan grade coffee dan mengklasifikasikan green beans agar kopi tergolong pada kualitas yang baik. Tujuan dari grade coffee dan pengklasifikasian green beans juga mengacu agar terciptanya kriteria kualitas kopi yang menyeluruh dan memudahkan dalam menetapkan harga jual produk secara adil. Namun, perlu diketahui bahwa sistematis penilaian grade coffee dan cara mengklasifikasikan green beans memiliki perbedaan, tidak akan sama secara universal mengingat tiap wilayah memiliki kultural yang berbeda.

Kultur sangat mempengaruhi perkembangan kopi di masing-masing wilayah, pengolahan biji kopi tiap daerah pastinya berkembang dari kultur sekitaran petani kopi. Tiap produsen kopi mengembangkan klasifikasi green beans dan grafik grade coffee sendiri, yang bahkan seringkali juga digunakan untuk menjadi penetapan standar minimum ekspor. 
Kegiatan pasca panen menentukan grade coffee dan mengklasifikasikan green beans yang dilakukan ini adalah penentuan grade coffee dan pengklasifikasian green beans berdasarkan ukuran dan biji kopi utuh. Dari hasil kegiatan ini diperoleh bahwa kelas mutu yang di hasilkan adalah mutu dengan masing-masing grade coffee $\mathrm{GI} \pm 60 \%$ (Rp. 50.000 per kg), GII $\pm 20 \%$ (Rp. 35.000 per $\mathrm{kg}$ ) dan GIII $\pm 20 \%$ (Rp. 15.000 per $\mathrm{kg}$ ), sehingga total nilai tambah diperleh rata-rata sebesar $15-20 \%$.

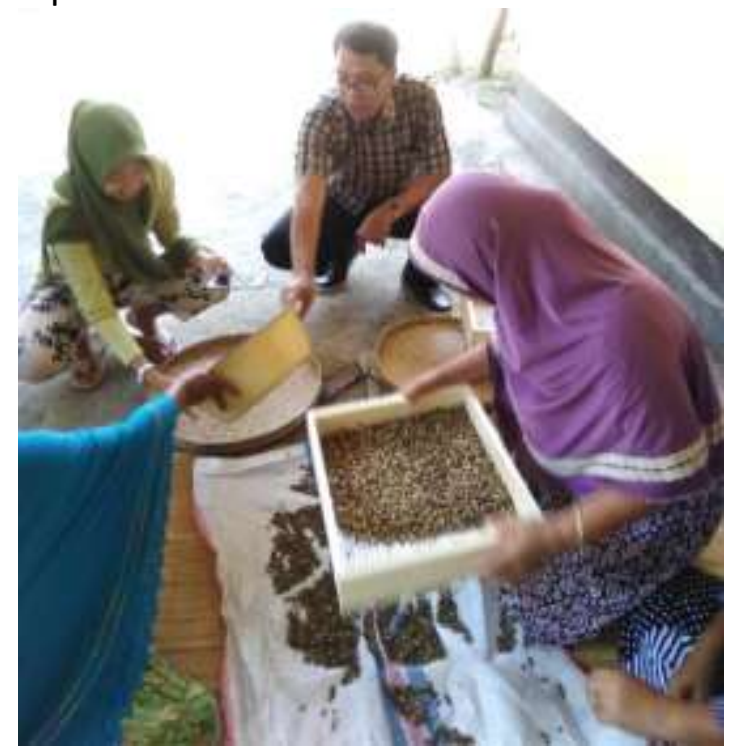

Gambar 6. Foto kegiatan sortasi dan grading biji kopi.

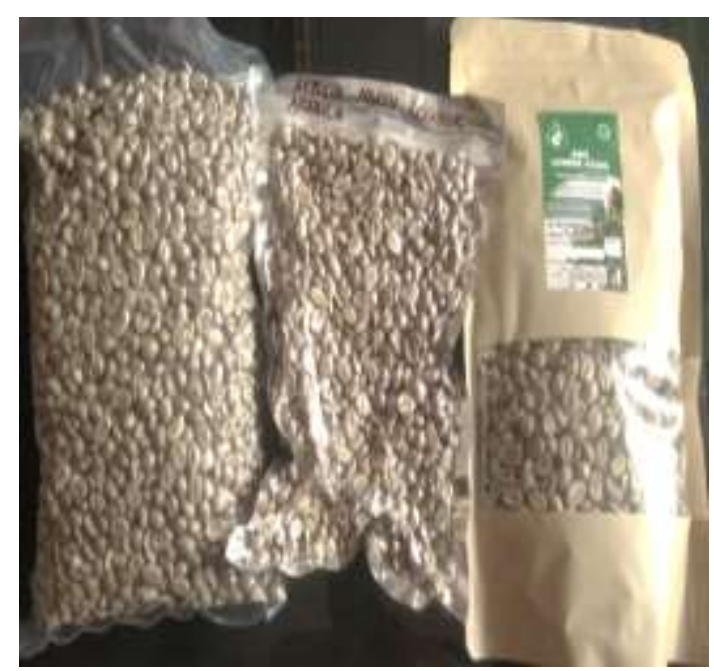

Gambar 7. Foto produk kopi kemasan hasil Gl (grade green beans coffee).
Kegiatan lainnya pada penerapan TTG pengolahan kopi adalah proses penyangraian biji kopi (roasting grenn bean) menggunakan alat penyangrai kopi semi otomatis tipe silinder berputar dengan kapasitas tabung 5-10 kg. Penyangraian merupakan suatu proses yang penting pada pembuatan kopi bubuk. Penyangraian bertujuan untuk menurunkan kadar air biji sampai di bawah 4\% dan bertujuan untuk membentuk aroma dan citarasa khas kopi. Proses penyangraian dapat menyebabkan perubahan fisik dan kimiawi yaitu penguapan air dari dalam biji, penguapan senyawa volatil (aldehid, furfural, keton, alkohol, dan ester), serta proses pirolisis atau pencoklatan biji.

Berdasarkan.suhu penyangraian yang digunakan kopi sangrai dibedakan atas 3 golongan yaitu ligh roast suhu yang digunakan $193-199^{\circ} \mathrm{C}$, medium roast suhu yang digunakan $204^{\circ} \mathrm{C}$ dan dark roast suhu yang digunakan $213-221^{\circ} \mathrm{C}$. Light roast menghilangkan 3-5\% kadar air, medium roast menghilangkan $\quad 5-8 \%$ dan dark roast menghilangkan $8-14 \%$ kadar air. Secara umum, kita akan mengenal 3 roast profile yaitu:

a. Light roast

Karakteristik aroma dan rasa kopi di light roast profile akan cenderung roasted grain, ringan, kafein dan keasaman yang dominan dan secara visual, profil warna biji kopi cenderung coklat terang.

b. Medium roast

Pada profil medium roast, fase yang terjadi adalah proses "caramelyzed" yang cenderung membentuk karakter aroma dan rasa "sweet" pada kopi. Pada fase ini roasted bean mengalami developing aroma dan rasa dari fase sebelumnya (first crack) sehingga lebih seimbang dari segi rasa, keasaman, kafein yang lebih sedikit dan memiliki profil tekstur yang lebih kental daripada light roast dan secara visual, medium roast memiliki warna coklat gelap. 


\section{c. Dark roast}

Pada fase dark roast, biji kopi telah melewati proses panjang yang menyebabkan banyak perubahan mulai dari berat yang semakin berkurang (ringan), warna yang lebih gelap (almost black) dengan kandungan minyak yang nampak pada permukaan biji kopi serta ukuran yang lebih besar dibandingkan dengan kondisi mula saat biji kopi masih mentah (raw green bean). Dalam dark roast profile ini proses "carbonyzed" terjadi pada biji kopi sehingga karakteristik aroma dan rasa kopi umumnya akan cenderung pahit, agak gosong dan kafeinnya paling sedikit.

Pada proses roasting green bean pada kelompok diterapkan hanya untuk menghasilkan biji kopi sangrai roast profile mediaum roast dan dark roast sesuai dengan permintaan pasar. Roasting ini dilakuka pada kisaran suhu $200-250^{\circ} \mathrm{C}$ selama 1-2 jam. Sebelum dilakukan penerapan TTG roasting biji kopi, telah dilakukan proses penyangraian dengan menggunakan alat penyangrai yang terbuat dari grabah dengan kapasitas 0,5-1 $\mathrm{kg} / \mathrm{jam}$. Biji kopi sangrai yang dihasilkan adalah dark roast dengan tingkat kematangan yang tidak seragam dan rasa lebih pahit.

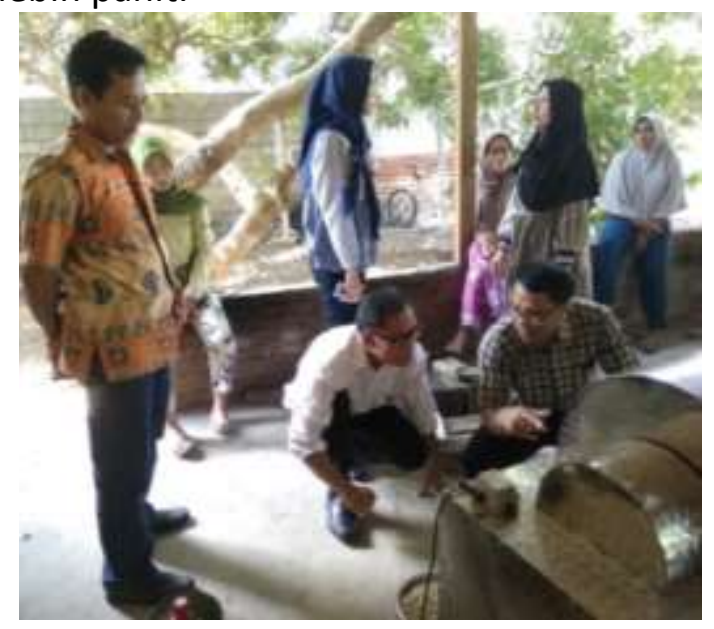

Gambar 8. Penjelasan penggunaan dan pengoperasian alat penyangrai (roaster green bean) kopi semi otomatis serta pemeliharaannya

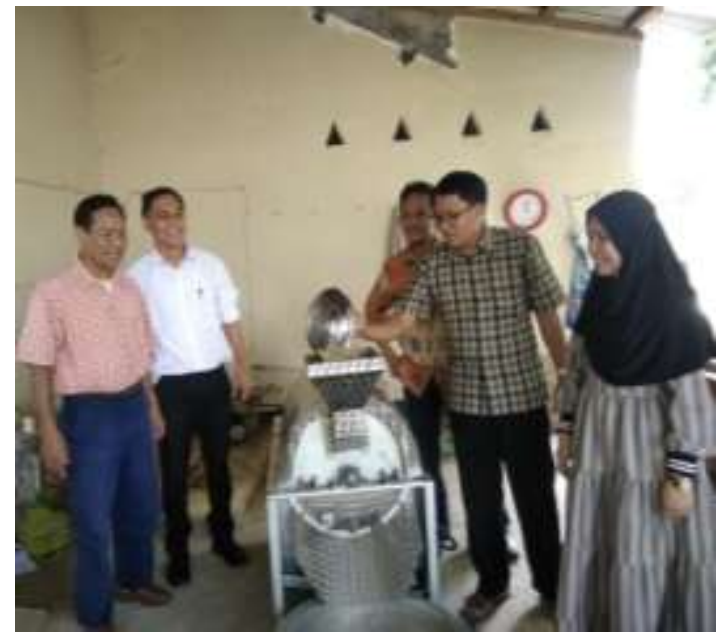

Gambar 9. Foto Proses Penyangraian Kopi

(Roast Bean) Menggunakan Alat Penyangrai Semi Otomatis

\section{Kegiatan Monitoring dan Evaluasi}

Setelah pelatihan dilaksanakan maka dilakukan monitoring kegiatan kelompok dalam pembuatan minyak kelapa tradisional (minyak jeleng) yang dilaksanakan 1 (satu) bulan setelah pelatihan. Kegiatan monitoring ini bertujuan untuk melihat hasil pelatihan yang sudah dilaksanakan dan sejauh mana masyarakat atau kelompok industri rumah tangga (home industries) mengaplikasikan ilmu dan keterampilan yang telah diperoleh dari kegiatan pelatihan serta mengevaluasi tingkat keberhasilan masyarakat dalam penerapan teknologi tepat guna teknik filtrasi pada pembuatan minyak kelapa tradisional.

Dari hasil monitoring dapat disimpulkan bahwa masyarakat setempat sangat antosias dengan melihat hasil olahannya dengan penerapan teknologi tepat guna teknik filtrasi pada pembuatan minyak kelapa tradisional. Antosiasme masyarakat dibuktikan dengan aktifitas masyarakat dalam pembuatan minyak kelapa tradisional, masing-masing kelompok membuat dan menghasilkan minyak kelapa tradisional sebanyak 10 liter per hari. Beberapa kendala yang dihadapi oleh masyarakat adalah wadah dan fasilitas 
yang masih terbatas, maka perlu dilakukan pembinaan lebih lanjut mengenai optimalisasi produksi melalui pengawalan dan pendampingan kelompok dalam memproduksi minyak kelapa tradisional (minyak jeleng).

\section{KESIMPULAN DAN SARAN}

\section{Kesimpulan}

Kegiatan pelatihan ini lebih ditekankan pada pemahaman penerapan teknologi tepat guna teknik filtrasi pada skala home idustries pembuatan minyak kelapa tradisional. Dengan penerapan teknologi tepat guna teknik filtrasi pada pembuatan minyak kelapa tradisional, masyarakat sangat merasakan kelebihan jika dibandingkan dengan tanpa penerapan teknologi tepat guna teknik filtrasi. Kelebihan yang diperoleh dengan penerapan teknologi tepat guna teknik filtrasi pada skala home idustries pembuatan minyak kelapa tradisional adalah mutu dan kualitasnya lebih tinggi dengan bau yang tidak cepat tengik, aroma dan rasa yang khas serta daya tahan yang lebih lama dengan daya simpan \pm 5-6 bulan. Kendala yang dihadapi oleh kelompok adalah wadah dan fasilitas yang masih terbatas, maka perlu dilakukan pembinaan lebih lanjut mengenai optimalisasi produksi melalui pengawalan dan pendampingan kelompok dalam memproduksi minyak kelapa tradisional.

\section{Saran}

Diperlukan perhatian dan peran serta pemerintah dalam pembinaan kelompok masyarakat yang berkelanjutan.

\section{DAFTAR PUSTAKA}

BPS, 2018. Kabupaten Lombok Utara dalam Angka. Nusa Tenggara Barat.

BPS, 2018. Provinsi Nusa Tenggara Barat dalam Angka. Nusa Tenggara Barat.

Diany Faila Sophia Hartatri, Lya Aklimawati, Jeffrey Neilson, 2019. Coffee and Cocoa Research Journal (CCRJ) Pusat Penelitian Kopi dan Kakao Indonesia (Puslitkoka) Indonesian Coffee and Cocoa Research Institute (ICCRI).

Nur Asni dan Araz Mailin, 2015. Teknologi Penanganan Pascapanen dan Pengolahan Hasil Kopi Liberika Tungkal Komposit (Libtukom). Balai Pengkajian Teknologi Pertanian Jambi Badan Penelitian dan Pengembangan Pertanian Kementerian Pertanian. Jakarta.

Rahardjo, Pudji. 2012. Panduan Budidaya dan Pengolahan Kopi Arabika dan Robusta. Penebar Swadaya. Jakarta 